\title{
Are poverty and protected area establishment linked at a national scale?
}

\author{
Caroline Upton, Richard Ladle, David Hulme, Tao Jiang, Dan Brockington and William M. Adams
}

\begin{abstract}
The debate about poverty and conservation draws mainly on local case studies, particularly of the impacts of protected areas. Although it is clear that local and contingent variables have important effects on the social and economic impacts of protected area establishment, it is not known whether there is a general relationship between national wealth and the area, number and type of protected area designated. Here we conduct such an analysis. Our results suggest that wealthy countries have a larger number of protected areas of smaller size than poorer countries. However, we find few significant relationships between indicators of poverty and the extent of protected areas at a national scale. Our analysis therefore confirms that relationships between poverty and conservation action are dynamic and locally specific. This conclusion has implications for
\end{abstract}

opposing positions within the debate on poverty and conservation. Critics of conservation who build upon local case studies to argue that protected areas make a significant contribution to poverty risk exaggerating the scale of the problem. However, conservation advocates also need to temper their enthusiasm. Outcomes in which both poverty alleviation and conservation goals are achieved may be possible in specific circumstances but clear choices will often need to be made between conservation and livelihood goals.

Keywords Biodiversity, conservation, poverty, protected areas, social impacts.

This paper contains supplementary material that can be found online at http://journals.cambridge.org

\section{Introduction}

There is considerable international policy debate concerning the relationship between biodiversity conservation policy and poverty (Sanderson \& Redford, 2003; Adams et al., 2004; Roe \& Elliott, 2004). Here we explore the possibility of a relationship between poverty and conservation, in the form of protected areas, at the national scale.

The consensus reached at the end of the 20th century on the primacy of poverty eradication as a global target,

Caroline Upton (Corresponding author) Department of Geography, University of Leicester, University Road, Leicester, LE1 7RH, UK. E-mail cu5@leicester.ac.uk

Richard Ladle Oxford University Centre for the Environment, Dyson Perrins Building, South Parks Road, Oxford, OX1 3QY, UK.

David Hulme and Dan Brockington Institute for Development Policy and Management, University of Manchester, Harold Hankins Building, Precinct Centre, Booth Street West, Manchester, M13 9QH, UK.

Tao Jiang Suite 2401, Harbour Ring Plaza, 18 Xi Zang Zhong Road, Shanghai 200001, China.

William M. Adams Department of Geography, University of Cambridge, Cambridge, CB2 3EN, UK

Received 29 November 2006. Revision requested 8 January 2007.

Accepted 3 February 2007. First published online 2 November 2007 and the dependence of many poor people on rural natural resources, can be interpreted as a powerful argument for biodiversity conservation. Biodiversity, in the sense of species and functioning ecosystems, provides local and wider benefits. These include food, water, timber, genomes, regulation of floods and climate, waste treatment, recreation and aesthetic enjoyment, soil formation, nutrient cycling, breeding grounds for prey, and plant pollination (Millennium Ecosystem Assessment, 2005). The local and global benefits of goods and services from intact ecosystems subject to sustainable use have been estimated to substantially outweigh those from converted systems subject to more intensive farming or forestry (Balmford et al., 2002).

The importance of sustainable environmental management to the livelihoods of the rural poor is recognized in the Millennium Development Goals. The proportion of land in protected areas is specified as one of five indicators of performance against Target 9, Goal 7 ('ensure environmental sustainability'; UN, 2005). The rationale for using the extent of land in protected areas as an indicator of environmental sustainability reflects not only conservation concerns but also the actual and potential contribution of protected areas to local livelihoods (World Bank, 2004), for example through direct usage, where access is permitted, or indirectly through tourism or other non-consumptive 
economic uses. The apparent linkages between poverty and conservation suggest that solutions can be identified that meet both livelihood and biodiversity goals (Timmer \& Juma, 2005), notwithstanding evidence that such solutions have proved elusive to date (Hulme \& Murphree, 2001; Adams et al., 2004; Agrawal \& Redford, 2006).

On the other hand, conservationists express concern at the extent to which, since the Rio Earth Summit in 1992, biodiversity has moved down the development agenda, and suggest that the pursuit of economic development in the name of poverty alleviation has become a major threat to biodiversity (Sanderson \& Redford, 2003; Sanderson, 2005). The compatibility of conservation and development are increasingly being called into question (Sanderson, 2005) and there is pessimism that solutions satisfying both agendas can be achieved on any scale.

\section{Poverty and protected areas}

The debate about poverty and conservation is particularly vigorous with respect to the social impacts of protected areas (West \& Brockington 2006), which are the dominant approach to in situ biodiversity conservation (Ravenel \& Redford, 2005). Globally there are $>105,000$ protected areas that cover $>20$ million $\mathrm{km}^{2}$, more than $11 \%$ of the Earth's land surface (Chape et al., 2005). There is conservation concern over the best means of safeguarding protected areas from development pressure (Brandon \& Wells, 1992; Brandon et al., 1998; Struhsaker, 1999; Terborgh, 1999) and renewed commitment to strictly protected parks, i.e. those that effectively prohibit human use and occupation, as the only effective strategy for conserving threatened biodiversity (Hutton et al., 2005). At the same time, however, there is policy concern over the impact of protected areas on local livelihoods (Brockington, 2002; Colchester, 2002; Brechin et al. 2003). While economic benefits from protected areas can be substantial (e.g. through wildlife tourism), net local socio-economic impacts can be strongly negative (Emerton, 2001). The biggest problem is involuntary displacement of human communities, defined to include not only the impacts of physical removal (Geisler \& de Sousa, 2001; Brockington, 2002; Colchester, 2002; Fortwangler, 2003) but also the restriction of access to resources in the more exclusionary categories of protected areas, including restrictions on the use of resources by people living outside a protected area (Cernea, 2006).

Policy debate about people and parks, as in the case of more general debates about conservation and poverty, is thus characterized by strong divisions of opinion, often grounded in data from a restricted number of specific case studies (Ghimire and Pimbert, 1997; Spinage, 1998; Terborgh, 1999; Geisler, 2003; Chapin 2004; Dowie, 2005). However, there are few systematic investigations of relationships between protected areas, poverty and prosperity on a larger scale (Brockington \& SchmidtSoltau, 2004; Brockington et al., 2006; de Sherbinin, 2008). Some studies do suggest that wider relationships between conservation and poverty exist. For example, Norton-Griffiths \& Southey (1995) explored the national opportunity costs caused by the enclosure of land in protected areas. Geisler \& de Sousa (2001) analysed the relationships between the extent of protected areas and national wealth in Africa and concluded that those countries with highest indices of poverty also have the greatest extent of protected areas in IUCN protected area categories I-V (IUCN, 1994). Geisler has also observed that between 1985 and 1997 poorer African countries gazetted many more protected areas than richer African countries (Geisler 2003). The current figure of total protected areas in the WDPA (World Database on Protected Areas; IUCN, 2005) is now nearly four times higher than the 29,000 that were recorded when Geisler published his research. This issue requires further examination.

The question of scale is important because the relationship between protected areas and poverty may only be observable at particular scales, such as the subnational (de Sherbinin, 2008) or local (Dasgupta et al., 2005). In this paper we explore whether poverty and conservation are linked at the national scale. If so, we might expect different numbers and kinds of protected area in countries with different levels of poverty. For example, richer countries may have more protected areas because they can afford them, and their larger conservation movements demand them; alternatively, poor countries may have more protected areas because they are dependent on foreign investment and therefore more likely to comply with protected area expansion agendas. We consider relationships between: (1) the extent and category of protected areas and World Bank national income categories, and (2) indicators of poverty and the extent of protected areas at the national scale.

\section{Methods}

In this analysis we include 136 countries listed in the World Bank World Development Indicators for 2005 (World Bank, 2005a). However, we exclude small countries (population $<1.5$ million), as their gross national income (GNI) per capita may be especially vulnerable to economic shocks, enabling them to move rapidly between national income groups. We also exclude small island states because our analysis is limited to terrestrial 
protected areas, and the considerable extent of marine protected areas typical of such states makes analysis in terms of terrestrial land area meaningless.

Countries were initially allocated to five World Bank income groups following the World Bank List of Economies, April 2005 (World Bank, 2005b): low, lower middle, upper middle, high income non-OECD (Organization for Economic Cooperation and Development) were in the high income non-OECD category. These were combined with high income OECD countries to form an aggregate category (High Income OECD/ non-OECD) in subsequent bivariate analyses.

Protected area data for each of the 136 countries are taken from the WDPA (IUCN, 2005) (Appendix). Polygon data on the extent of protected areas were used where available. We analyse only terrestrial protected areas as data on the extent of marine territorial claims were not readily available. We exclude proposed and degazetted protected areas. IUCN has identified six categories of protected areas according to management objectives to act as common labels for protected areas established at the national level (IUCN, 1994; Bishop et al., 2004). Categories Ia, Ib and II strictly exclude significant human occupation and resource use, and potentially have the most significant impacts on local livelihoods. Categories III and IV refer to protected areas with lesser degrees of constraint on users, categories $\mathrm{V}$ and VI the least (Bishop et al., 2004; Ravenel \& Redford, 2005). We use three protected area indicators according to the degree to which protected areas potentially constrain human economic activity: (1) total proportion of country protected (all six IUCN categories); (2) proportion of country in IUCN Categories Ia, Ib and II; (3) proportion of country in IUCN Categories Ia, Ib, II, III and IV (Appendix; country area data are from World Bank, 2005a). Individual country data from WDPA (IUCN, 2005) and income group allocations from the World Bank List of Economies (World Bank, 2005b) are used as a basis for calculation of protected area indicators by World Bank income group (Table 1). In addition, we also calculate average sizes of individual protected areas by country and World Bank income group (Table 1, Appendix). The latter data is used to examine fully the distribution and characteristics of protected areas by income groups.

Data on poverty were obtained primarily from World Bank (2005a) and UNDP (2004). There are many possible indicators and definitions of poverty in current use. All available national level indicators have their limitations, typically failing to capture sub-national diversity and to represent subsistence-based rural livelihoods (Karshenas, 2004/2005; Reddy \& Pogge, 2005). We use GNI per capita calculated by Atlas and Purchasing Power Parity and high income OECD. Of the 136 countries only four

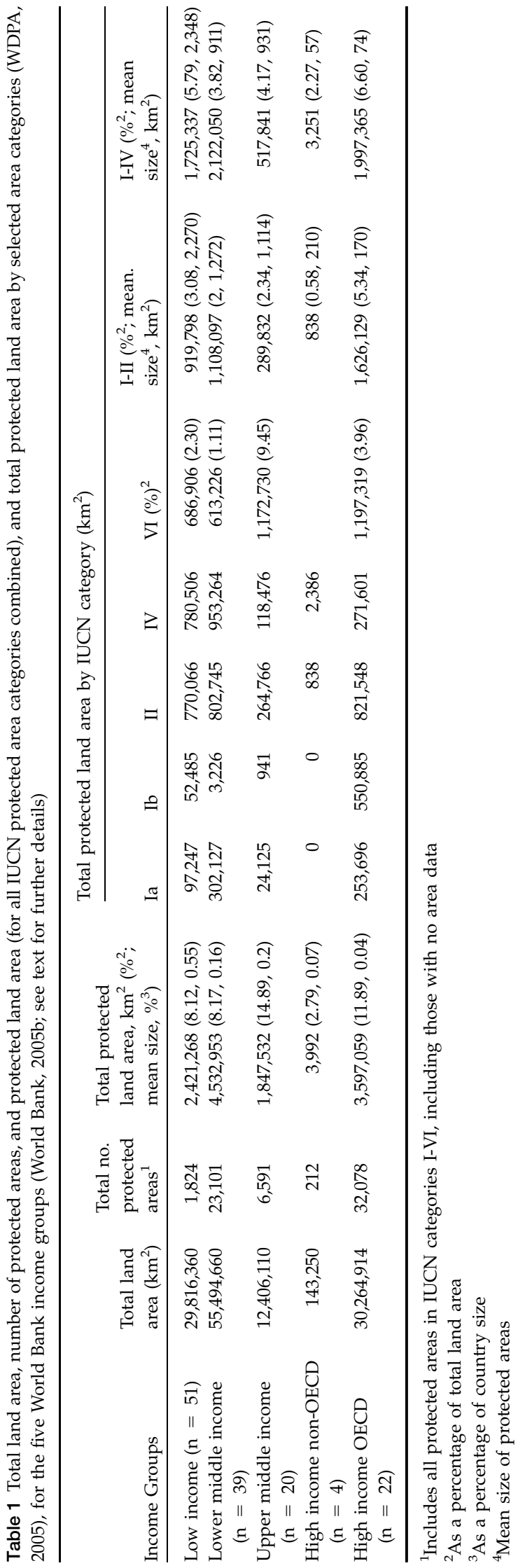

(c) $2008 \mathrm{FFI}$, Oryx, 42(1), 19-25 
(PPP) methods, the percentage of population living on $<$ USD 1 per day, and the Human Development Index (HDI) from the suite of possible indicators on the basis of their widespread availability and usage, the importance of the $\angle$ USD 1 per day indicator in poverty debates, and the need for monetary and non-monetary indicators. Data for the $<$ USD 1 per day indicator were taken from McKay et al. (2004) for Uganda, Pakistan, Democratic Republic of Congo, North Korea and Sudan, rather than from World Bank (2005a) because of concerns with data availability and accuracy (Appendix).

Spearman's 2-tailed rank correlations were performed on poverty and protected area indicators to identify covariation between the nature and extent of protected areas and poverty, both for the full dataset and by World Bank income group. Spearman's rank correlations are selected as the most robust and conservative given the presence of outliers in the dataset and/or non-normal distribution for many analyses.

\section{Results}

\section{Distribution and characteristics of protected areas by country income groups}

Table 1 provides a summary of the number and percentage of protected areas by IUCN categories in the five national income groups. The upper middle income group of countries has the greatest percentage of land in protected areas $(14.89 \%$ of total land area). The average size of individual protected areas in richer countries is small compared to country area $(0.04 \%$ of land area for high income OECD countries; Table 1). Where more restrictive Category I-II and I-IV protected areas occur these are small compared to those in poorer countries (average size of Category I-II protected areas is $170 \mathrm{~km}^{2}$ for high income OECD countries, as opposed to $2,270 \mathrm{~km}^{2}$ for low income countries; Table 1). However, the least restrictive Category VI dominates the protected area estate in terms of the total land area dedicated to any single protected area category in these wealthier countries (Table 1). In upper middle income countries most protected areas are of intermediate size, and again the least restrictive Category VI designation is most extensive, in this case exceeding even the composite categories I-II and I-IV as a percentage of land area (Table 1). In contrast, protected areas in low income countries (dominated by sub-Saharan Africa) are fewer but, on average, orders of magnitude larger both absolutely and as a proportion of country size (Table 1). In summary, protected areas in the poorest countries tend to be individually larger and in the more restrictive categories. In richer countries the overall area protected is larger but this total is made up of numerous smaller protected areas.

\section{Protected areas and poverty indicators}

Analysis of selected poverty indicators at national level for the whole dataset demonstrates weak negative correlations with the extent of different protected area categories (Table 2). There are positive correlations between protected area indicators and HDI in wealthy countries, suggesting that wealthy countries have placed more land in protected areas. There are no correlations between poverty and protected area indicators for other national income groups (Table 2).

\section{Discussion}

Our analysis shows that the distribution, size and category of protected areas vary between countries of different income groups. Poorer countries tend to have fewer, larger protected areas, often dominated by the more restrictive categories, whereas high income OECD countries tend to have smaller, fragmented protected

Table 2 Significant spearman rank correlations between protected area (WDPA, 2005) ${ }^{1}$ and poverty indicators ${ }^{2}$, for all countries in database and by World Bank income groups. See text for further details.

\begin{tabular}{|c|c|c|}
\hline Income Groups & Correlation & Statistics \\
\hline \multirow[t]{4}{*}{ All countries } & GNI per capita (PPP) \& category I-II protected areas as \% total land area & $\mathrm{n}=128, r_{\mathrm{s}}=-0.178, \mathrm{P}=0.045$ \\
\hline & HDI \& category I-IV protected areas as \% total land area & $\mathrm{n}=130, r_{\mathrm{s}}=-0.184, \mathrm{P}=0.036$ \\
\hline & GNI per capita (Atlas) \& category I-IV protected areas as $\%$ total land area & $\mathrm{n}=130, r_{\mathrm{s}}=-0.213, \mathrm{P}=0.015$ \\
\hline & GNI per capita (PPP) \& category I-IV protected areas as \% total land area & $\mathrm{n}=128, r_{\mathrm{s}}=-0.224, \mathrm{P}=0.011$ \\
\hline High income & HDI \& category I-II protected areas as \% total land area & $\mathrm{n}=26, r_{\mathrm{s}}=0.557, \mathrm{P}=0.003$ \\
\hline OECD/non-OECD & HDI \& category I-IV protected areas as $\%$ total land area & $\mathrm{n}=26, r_{\mathrm{s}}=0.425, \mathrm{P}=0.03$ \\
\hline
\end{tabular}

${ }^{1}$ Protected area indicators are total land in protected areas (all IUCN categories) as a percentage of total land area, and land area in IUCN categories I-II and I-IV as a percentage of total land area.

${ }^{2}$ Poverty indicators are GNI per capita calculated using the World Bank Atlas method, GNI per capita calculated using purchasing power parity (PPP), and the Human Development Index (HDI). GNI data were taken from World Bank (2005a) and HDI figures from UNDP (2004). 
area systems, although overall a larger protected area estate. Upper middle income countries have particularly large percentages of their land areas set aside for conservation in protected areas.

However, there is no clear relationship between the area of land in protected areas and national levels of poverty or wealth. Our analysis identifies weak significant relationships between the size of the protected area estate (as \% of total land area in IUCN categories I-II and I-IV) and poverty at the national scale, which vary according to national income category. Wealth and the extent of protected areas are positively correlated in the wealthiest economies but not in the poorest countries. In all instances correlations account for $<35 \%$ of covariation, thus highlighting the existence of contingent conditions and variables that these national level indicators fail to reflect or capture. In no income-based category of countries do the economic and social effects (whether positive or negative) of conservation in the form of protected areas have a substantial effect on aggregate, national poverty statistics. Negative impacts on local livelihoods of the kind reported in case studies (Brockington, 2002; Emerton, 2001) are not reflected in national level data. De Sherbinin (2008) does note significant correlations between sub-national poverty indicators and large, restrictive protected areas in low income countries, although causal relationships remain unclear.

Clearly, while negative (or positive) socio-economic impacts of protected area designation may be significant for local residents and the local economy, particularly in poorer, resource-dependent communities (as micro-scale studies show: Brockington, 2002; Colchester, 2002; Timmer \& Juma, 2005), these effects are not discernible at the national scale. The most likely explanation for this is simply that the number of people adversely affected by protected areas is small compared to the number of poor people nationally, even in countries with extensive rural poverty and large protected area estates. Significant factors here are likely to be dilution (the numbers affected by protected areas being small compared to national population size), and the proportion of the poor who live in urban as opposed to rural areas. As the urban population grows, the relative national significance of any impacts of protected areas on rural populations may be expected to fall. Local negative impacts of protected areas could increase levels of rural-urban migration and reduce any rural-urban economic remittances. However, such effects are unlikely to affect sufficient numbers of people to be discernible in national level statistics. Similarly, urban benefits from the preservation of habitat in protected areas (e.g. ecosystem services such as fresh water) are unlikely to be measurable at the national scale given the range of factors affecting urban poverty.
These are not surprising conclusions. As is obvious from numerous case studies (Ghimire \& Pimbert, 1997; Spinage, 1998; Brechin et al., 2003; Dowie, 2005), a multitude of intervening site specific and contextual variables shape the effect of protected areas on local wealth or poverty. Our conclusion supports suggestions that the relationships between poverty and conservation are dynamic and often locally specific (Adams et al., 2004). It suggests, however, in agreement with de Sherbinin (2008), that at larger scales the relationships between protected areas and poverty remain indeterminate, and counters the suggestion that more protected areas are associated with greater poverty at the national scale (Geisler, 2003). Our conclusion also questions the wisdom of the Millennium Development Goals (UN, 2005) in using the extent of protected areas as an indicator of progress in achieving the livelihood dimensions of sustainability. While the total extent of protected areas may be a good measure of success in protecting biodiversity, it is not an effective measure of those aspects of environmental quality and accessibility relevant to poverty alleviation.

This analysis is useful in the context of the debate concerning 'people and parks' (Brandon \& Wells, 1992; Fortwangler, 2003; Hutton et al., 2005; West \& Brockington, 2006). It suggests that critics of conservation who build upon local case studies to erect a systematic critique of protected areas as a significant cause of poverty risk exaggerating the scale of the problem. On the other hand, those conservation advocates who see protected areas as the cornerstone of sustainable development strategies that can alleviate poverty nationally also need to temper their enthusiasm. It may be possible to find outcomes in which both poverty alleviation and conservation goals are achieved in some specific, possibly unusual, circumstances. However, very often, clear choices will need to be made between the relative importance of conservation and livelihood goals.

\section{Acknowledgements}

We thank the UK Poverty and Conservation Working Group for many discussions. We also thank staff at the Chronic Poverty Research Centre, Institute for Development Policy and Management, University of Manchester, and Institute of Development Studies, University of Sussex, for discussions in the early stages of the work.

\section{References}

Adams, W., Aveling, R., Brockington, D., Dickson, B., Elliot, J., Hutton, J., Roe, D., Vira, B. \& Wolmer, W. (2004) Biodiversity conservation and the eradication of poverty. Science, 306, 1146-1149. 
Agrawal, A. \& Redford, K. (2006) Poverty, Development, and Biodiversity Conservation: Shooting in the Dark? WCS Working Paper No. 26. Wildlife Conservation Society, New York, USA.

Balmford, A., Bruner, A., Cooper, P., Costanza, R., Farber, S., Green, R., Jenkins, M., Jefferiss, P., Jessamy, V., Madden, J., Munro, K., Myers, N., Naeem, S., Paavola, J., Rayment, M., Rosendo, S., Roughgarden, J., Trumper, K. \& Turner, R. (2002) Economic reasons for conserving wild nature. Science, 297, 950-953.

Bishop, K., Dudley, N., Phillips, A. \& Stolton, S. (2004) Speaking a Common Language: The Uses and Performance of the IUCN System of Management Categories for Protected Areas. Cardiff University, IUCN, and UNEP-World Conservation Monitoring Centre, Cambridge, UK.

Brandon, K.E., Redford, R. \& Sanderson, S. (1998) Parks in Peril: People, Politics and Protected Areas. Island Press, Washington, DC, USA.

Brandon, K.E. \& Wells, M. (1992) Planning for people and parks: design dilemmas. World Development, 20, 557-570.

Brechin, S.R., Wilshusen, P.R., Fortwangler, C.L. \& West, P.C. (2003) Contested Nature. Promoting International Biodiversity with Social Justice in the Twenty-First Century. State University of New York Press, New York, USA.

Brockington, D. (2002) Fortress Conservation: The Preservation of the Mkomazi Game Reserve, Tanzania. James Currey, Oxford, UK.

Brockington, D., Igoe, J. \& Schmidt-Soltau, K. (2006)

Conservation, human rights, and poverty reduction Conservation Biology, 20, 250-252.

Brockington, D. \& Schmidt-Soltau, K. (2004) The social and environmental impacts of wilderness and development. Oryx, 38, 140-142.

Bruner, A., Gullison, R., Rice, R. \& da Fonesca, G. (2001) Effectiveness of parks in protecting tropical biodiversity. Science, 291, 125-128.

Cernea, M.M. (2006) Population displacement inside protected areas: a redefinition of concepts in conservation politics. Policy Matters, 14, 8-26.

Chape, S., Harrison, J., Spalding, M. \& Lysenko, I. (2005) Measuring the extent and effectiveness of protected areas as an indicator for meeting global biodiversity targets. Philosophical Transactions of the Royal Society B, 360, 443-455.

Chapin, M. (2004) A challenge to conservationists. World Watch Magazine, 17, 17-31.

Colchester, M. (2002) Salvaging Nature: Indigenous Peoples, Protected Areas and Biodiversity Conservation. World Rainforest Movement, Montevideo, Uruguay.

Dasgupta, S., Deichmann, U., Meisner, C. \& Wheeler, D. (2005) Where is the poverty-environment nexus? Evidence from Cambodia, Lao PDR, and Vietnam. World Development, 33, 617-638.

de Sherbinin, A. (2008) An assessment of infant mortality rates around protected areas in developing countries. Oryx, 42, $\mathrm{XX}-\mathrm{XX}$.

Dowie, M. (2005) Conservation Refugees. When Protecting Nature Means Kicking People Out. Http://www.orionmagazine.org/ index.php/articles/article/161/ [accessed 5 October 2006].

Emerton, L. (2001) The nature of benefits and the benefits of nature. Why wildlife conservation has not economically benefited communities in Africa. In African Wildlife and Livelihoods: The Promise and Performance of Community Conservation (eds D. Hulme \& M. Murphree), pp. 208-226. James Currey, London, UK.
Fortwangler, C. (2003) The winding road: incorporating social justice and human rights into protected areas policies. In Contested Nature: Promoting International Biodiversity Conservation with Social Justice in the Twenty-First Century (eds S.R. Brechin, P.R. Wilshusen, C.L. Fortwangler \& P.C. West), pp. 25-40. State University of New York Press, New York, USA.

Geisler, C. (2003) A new kind of trouble: evictions in Eden. International Social Science Journal, 55, 69-78.

Geisler, C. \& de Sousa, R. (2001) From refuge to refugee: the African case. Public Administration and Development, 21, 159-170.

Ghimire, K.B. \& Pimbert, M.P. (1997) Social Change and Conservation. Earthscan, London, UK.

Hulme, D. \& Murphree, M. (eds) (2001) African Wildlife and Livelihoods: The Promise and Performance of Community Conservation. James Currey, Oxford, UK.

Hutton, J., Adams, W.M. \& Murombedzi, J. (2005) Back to the barriers: changing narratives in biodiversity conservation. Forum for Development Studies, 32, 341-370.

IUCN (1994) Guidelines for the Management of Protected Areas. IUCN, Gland, Switzerland [http:/ /www.unep-wcmc.org/ protected_areas/categories/eng/index.html, accessed 11 December 2005].

IUCN (2005) World Database on Protected Areas 2005. IUCN, Gland, Switzerland [http://sea.unep-wcmc.org/wdbpa/, accessed 15 December, 2005].

Karshenas, M. 2004/5) Global Poverty Estimates and the Millennium Goals: Towards a Unified Framework. International Labour Organization, Geneva, Switzerland.

McKay, A., Baulch, B., Hisarciklilar, M. \& Lawson, D. (2004) How Many Chronically Poor People are there in the World? Some Preliminary Estimates. CPRC Working Paper No. 45. Chronic Poverty Research Centre, Manchester, UK [http:// www.chronicpoverty.org/pdfs/45McKay_Baulch.pdf, accessed 11 December 2005].

Millennium Ecosystem Assessment (2005) Ecosystems and Human Well-Being: Synthesis. Island Press, Washington, USA.

Norton-Griffiths, M. \& Southey, C. (1995) The opportunity costs of biodiversity conservation in Kenya. Ecological Economics. 12, 125-139.

Ravenel, R. \& Redford, K. (2005) Understanding IUCN protected area categories. Natural Areas Journal, 25, 381-389.

Reddy, S.G. \& Pogge, T. (2005) How Not to Count the Poor. Http://ssrn.com/abstract=893159 [accessed 15 December 2005].

Roe, D. \& Elliott, J. (2004) Poverty reduction and biodiversity conservation: rebuilding the bridges. Oryx, 38, 137-139.

Sanderson, S. (2005) Poverty and conservation: the new century's 'peasant question'. World Development, 33, 323-332.

Sanderson, S. \& Redford, K. (2003) Contested relationships between biodiversity conservation and poverty alleviation. Oryx, 37, 389-390.

Spinage, C. (1998) Social change and conservation misrepresentation in Africa. Oryx, 32, 265-276.

Struhsaker, T.T. (1999) Ecology of an African Rain Forest: Logging in Kibale and the Conflict between Conservation and Exploitation. University Press of Florida, Gainesville, USA.

Terborgh, J. (1999) Requiem for Nature. Island Press, Washington, DC, USA.

Timmer, V. \& Juma, C. (2005) Taking root: biodiversity conservation and poverty reduction come together in the 
tropics. Environment: Science and Policy for Sustainable Development, 47, 24-44.

UN (2005) UN Millennium Development Goals. Http:// www.un.org/millenniumgoals/ [accessed 10 December 2005].

UNDP (United Nations Development Programme) (2004) Human Development Report 2004. Http://hdr.undp.org/ reports/global/2004/pdf/hdr04_complete.pdf [accessed 12 December 2005].

West, P. \& Brockington, D. (2006) An anthropological perspective on some unexpected consequences of Protected Areas. Conservation Biology, 20, 609-616.

World Bank (2004) A Complete Listing of the Goals, Targets, and Indicators for MDGs. Http://devdata.worldbank.org/gmis/ mdg/list_of_goals.htm [accessed 15 November 2005].

World Bank (2005a) World Development Indicators 2005. Http:// www.worldbank.org/data/wdi2005 [accessed 12 December 2005].

World Bank (2005b) World Bank List of Economies, April 2005. Http:/ / www.worldbank.org/data/countryclass / classgroups.htm [accessed 12 December 2005].

\section{Appendix}

The appendix for this article is available online at http://journals.cambridge.org

\section{Biographical sketches}

Caroline Upton works on pastoralism and institutional change, and her current research interests include the impacts of conservation policy and practice on pastoral livelihoods. Richard Ladle's research interests include conservation biogeography and market-led solutions to the biodiversity crisis. David Hulme's research interests are in poverty reduction and conservation. Tao Jiang is an environmental consultant. Dan Brockington is working on a comparative global assessment of eviction and exclusion from protected areas. Bill Adams has a particular interest in the history of conservation and the development of conservation strategies that take account of human needs. 